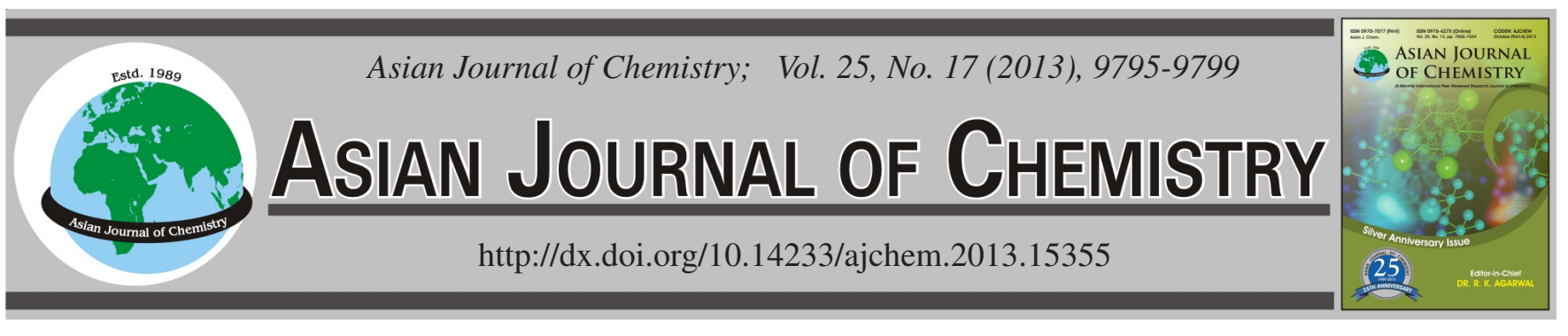

\title{
Environmental Chemistry of Groundwater Near an Industrial Area, Northwest China
}

\author{
Jianhua Wu ${ }^{1,2}$, Peiyue LI $^{1,2, *}$ and Hui Qian ${ }^{1,2}$
}

${ }^{1}$ School of Environmental Science and Engineering, Chang'an University, No. 126 Yanta Road, Xi'an 710054, P.R. China

${ }^{2}$ Key Laboratory of Subsurface Hydrology and Ecology in Arid Areas, Ministry of Education, No. 126 Yanta Road, Xi'an 710054, P.R. China

*Corresponding author: Fax: +86 29 82339952; Tel: +86 29 82339327; E-mail: lipy2@163.com; wjh2005xy@126.com

(Received: 18 February 2013;

Accepted: 23 October 2013)

AJC-14277

\begin{abstract}
An entropy-weighted water quality index was applied to assess the groundwater quality near an industrial park (China) where several metal smelting plants are located. The study shows that most physiochemical parameters except $\mathrm{HCO}_{3}^{-}, \mathrm{NO}_{3}-\mathrm{N}$, TDS, total hardness, $\mathrm{F}$ and $\mathrm{Mn}$ are within the permissible limits of WHO standard or national standard of China. The excessive $\mathrm{HCO}_{3}^{-}$, TDS, total hardness and $\mathrm{F}^{-}$are caused mainly by natural rock weathering processes, while that of $\mathrm{NO}_{3}-\mathrm{N}$ is caused by agricultural activities and the high content of $\mathrm{Mn}$ in groundwater is induced by both natural and human processes. The water quality indexes range from 27.94 to $128.94 \%$. Sixty five per cent of the total samples are of medium quality, $25 \%$ are of good quality and the remaining $10 \%$ are of poor quality. The high water quality indexes are caused by the excess $\mathrm{NO}_{3}-\mathrm{N}$, total hardness and $\mathrm{Mn}$ which are mostly human induced.
\end{abstract}

Key Words: Water quality assessment, Water quality index, Groundwater pollution, Anthropogenic interference.

\section{INTRODUCTION}

Groundwater is a vital source of domestic, industrial, agricultural uses in arid areas where precipitation and fresh surface water are limited.With the rapid development of industry and population growth in developing countries like China, human activity induced groundwater over-exploitation and pollution have become more and more serious. It is reported that there are as many as 2.8 million wells in China ${ }^{1}$ and the heavy groundwater extraction has caused many problems such as groundwater level drop, salt water intrusion, ground surface depression, etc. In addition, nitrate pollution caused by agricultural activities has also been widely reported in many parts of $\mathrm{China}^{2-6}$. All these reports have indicated that China faces a serious situation of groundwater pollution.

These years, many water quality assessment methods have been proposed ${ }^{7,8}$. Water quality index (WQI) is a relatively easy tool and it has been widely used all over the world for the quality assessment of groundwater and surface water. Bordalo et al. ${ }^{9}$ used a modified nine-parameter Scottish water quality index to assess the monthly water quality of the Douro river, an internationally shared river, during a 10-year period (19922001), while Chaturvedi et al. ${ }^{10}$ assessed the groundwater quality near an industrial area of Balrampur city, India.

Zhongning Shikong industrial area is located in the north bank of the Yellow river, Zhongning County, covering an area of $54 \mathrm{~km}^{2}$. There are several metal smelting plants in this area such as Ningxia Tianyuan Manganese Company Limited which is the largest manganese manufacturer in the world. The industrial production in this area has brought vast profits to local economy. However, at the same time, it also brings groundwater pollution. Therefore, the aim of the study is to investigate the environmental chemistry of groundwater and assess its quality using the internationally used method.

\section{EXPERIMENTAL}

Water sample collection and analysis: Twenty samples were collected in July 2012 from hand pumping wells and the sampling locations are shown in Fig. 1. Samples were analyzed by the laboratory of Ningxia Environmental Protection Office. Each of the groundwater samples was analyzed for major ions $\left(\mathrm{Na}^{+}, \mathrm{K}^{+}, \mathrm{Ca}^{2+}, \mathrm{Mg}^{2+}, \mathrm{Cl}^{-}, \mathrm{SO}_{4}{ }^{2-}, \mathrm{HCO}_{3}{ }^{-}, \mathrm{CO}_{3}{ }^{2-}, \mathrm{F}^{-}, \mathrm{NH}_{4}{ }^{+}-\mathrm{N}\right.$, $\mathrm{NO}_{3}{ }^{-}-\mathrm{N}, \mathrm{NO}_{2}^{-}-\mathrm{N}$ ), $\mathrm{pH}$, chemical oxygen demand (COD), total dissolved solid (TDS), total hardness (TH), metasilicic acid, arsenic, volatile phenol, cyanide and heavy metals (copper, aluminum, manganese, zinc, cadmium, mercury, nickel, lead and chromium). During the sample collection, transportation and preservation, all procedures followed standard requirement raised by the Chinese Ministry of Water Resources to ensure the consistency of data.

Entropy-weighted water quality index: Entropy-weighted water quality index (EWQI) is an improved water quality index which considers the different significances of different physiochemical indices to the water quality ${ }^{11,12}$. This method has been introduced in our previous studies ${ }^{11,12}$. Since the limit 


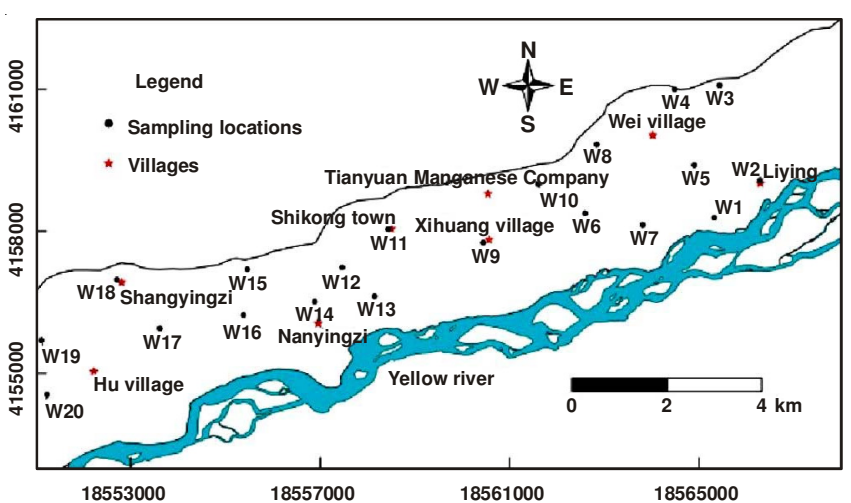

Fig. 1. Study area and sampling locations

of $\mathrm{pH}$ in the drinking water quality standard of China is 6.5 to 8.5 , it is a little different for the quality rating scale calculation of $\mathrm{pH}$. In the present study, the quality rating scale of $\mathrm{pH}$ is calculated with the following formula ${ }^{12}$ :

$$
\mathrm{q}_{\mathrm{pH}}=\frac{\mathrm{C}_{\mathrm{pH}}-7}{8.5-7} \times 100
$$

where $\mathrm{q}_{\mathrm{pH}}$ is the quality rating scale of $\mathrm{pH}, \mathrm{C}_{\mathrm{pH}}$ is the observed value of $\mathrm{pH}, 8.5$ and 7 are the maximum permissible value and ideal value of $\mathrm{pH}$ for drinking purpose, respectively.

The EWQI can be calculated by the formula below:

$$
\text { EWQI }=\sum_{j=1}^{n} \text { WQI }_{j}=\sum_{j=1}^{n} \omega_{j} q_{j}
$$

where, $q_{j}$ is quality rating scale for each parameter, $\omega_{\mathrm{j}}$ is entropy weight of each index. It can be calculated as per the processes introduced by Li et al. ${ }^{7,11}$.Groundwater may be classified into five ranks ranging from "excellent water" to "extremely poor water". The classification is listed in Table-1.

\section{RESULTS AND DISCUSSION}

General hydrochemical characteristics: A statistical analysis was performed to show the general groundwater hydrochemical characteristics and the results are shown in Table-2. According to the statistics, all parameters, except $\mathrm{HCO}_{3}{ }^{-}, \mathrm{NO}_{3}-\mathrm{N}$, TDS, total hardness, $\mathrm{F}^{-}$and $\mathrm{Mn}$, are within

\begin{tabular}{ccl}
\multicolumn{3}{c}{ TABLE-1 } \\
CLASSIFICATION OF GROUNDWATER \\
QUALITY AS PER EWQI
\end{tabular}

the permissible limits of WHO standard or national standard of China. The parameters that have beyond the permissible limits of standards have been graphed in Fig. 2 to show their distributions so that important and useful information can be provided to the local decision makers.

Most of the major ions except $\mathrm{HCO}_{3}{ }^{-}$are within the permissible limits of the WHO and the national standards. Generally speaking, the major ions come mainly from the minerals of the aquifer media. $\mathrm{HCO}_{3}{ }^{-}$in groundwater usually comes from mineral weathering such as the dissolution of calcite and dolomite, which can be expressed by the following equations.

$$
\mathrm{CaCO}_{3}+\mathrm{H}_{2} \mathrm{O}+\mathrm{CO}_{2}=\mathrm{Ca}^{2+}+2 \mathrm{HCO}_{3}^{-}
$$

$\mathrm{CaMg}\left(\mathrm{CO}_{3}\right)_{2}+2 \mathrm{H}_{2} \mathrm{O}+\mathrm{CO}_{2}=4 \mathrm{HCO}_{3}^{-}+\mathrm{Ca}^{2+}+\mathrm{Mg}^{2+}$

The dissolution of these minerals is usually very slow. However, under anthropogenic interference, groundwater hydrodynamic conditions may be changed, thus accelerating the reaction speed. It shows a decreasing trend from northwest to southeast with the Yellow river approached (Fig. 3a). It can be inferred that the $\mathrm{HCO}_{3}{ }^{-}$may be influenced a lot by the Yellow river water.

$\mathrm{NH}_{4}{ }^{+}, \mathrm{NO}_{3}{ }^{-}$and $\mathrm{NO}_{2}^{-}$are indicators of anthropogenic pollution ${ }^{5}$. The three forms of nitrogen compounds can transform into each other under proper conditions. The reactions can be expressed as follows:

$$
\begin{gathered}
2 \mathrm{NH}_{4}^{+}+\mathrm{O}_{2} \stackrel{\text { Nitrite bacteria }}{\longrightarrow} 2 \mathrm{NO}_{2}^{-}+2 \mathrm{H}_{2} \mathrm{O}+4 \mathrm{H}^{+} \\
2 \mathrm{NO}_{2}^{-}+\mathrm{O}_{2} \stackrel{\text { Nitrobacteria }}{\longrightarrow} 2 \mathrm{NO}_{3}^{-}
\end{gathered}
$$

TABLE-2

STATISTICS OF WATER SAMPLES COLLECTED FROM THE STUDY AREA

\begin{tabular}{ccccccccc}
\hline Index & Unit & Sample numbers & WHO standard & National standard & Minimum & Maximum & Mean & Standard deviation \\
\hline $\mathrm{Ca}^{2+}$ & $\mathrm{mg} / \mathrm{L}$ & 20 & 200 & - & 31.8 & 173 & 102.1 & 37.5 \\
$\mathrm{Mg}^{2+}$ & $\mathrm{mg} / \mathrm{L}$ & 20 & 150 & - & 27.9 & 79.93 & 57.42 & 17.77 \\
$\mathrm{Na}^{+}$ & $\mathrm{mg} / \mathrm{L}$ & 20 & 200 & 200 & 41.9 & 200 & 97.48 & 40.51 \\
$\mathrm{~K}^{+}$ & $\mathrm{mg} / \mathrm{L}$ & 20 & 200 & - & 2.65 & 6.65 & 4.27 & 1.21 \\
$\mathrm{HCO}_{3}^{-}$ & $\mathrm{mg} / \mathrm{L}$ & 20 & 600 & - & 158.51 & 844.22 & 372.99 & 161.54 \\
$\mathrm{SO}_{4}^{2-}$ & $\mathrm{mg} / \mathrm{L}$ & 20 & 600 & 250 & 84.3 & 548 & 185.6 & 114.2 \\
$\mathrm{Cl}^{-}$ & $\mathrm{mg} / \mathrm{L}$ & 20 & 600 & 250 & 50.4 & 190 & 92.37 & 36.72 \\
$\mathrm{NO}_{3}-\mathrm{N}$ & $\mathrm{mg} / \mathrm{L}$ & 20 & 11 & 10 & 5.74 & 25.74 & 13.8 & 5.66 \\
$\mathrm{~F}$ & $\mathrm{mg} / \mathrm{L}$ & 20 & 1.5 & 1 & 0.23 & 2.08 & 0.6 & 0.44 \\
$\mathrm{TDS}$ & $\mathrm{mg} / \mathrm{L}$ & 20 & - & 1000 & 414 & 1576 & 807.2 & 292.6 \\
$\mathrm{pH}$ & - & 20 & - & $6.5-8.5$ & 7.54 & 8.28 & 7.83 & 0.21 \\
$\mathrm{TH}$ & $\mathrm{mg} / \mathrm{L}$ & 20 & - & 450 & 261 & 746 & 442 & 135 \\
$\mathrm{Cu}$ & $\mathrm{mg} / \mathrm{L}$ & 20 & 2 & 1 & 0.0044 & 0.1761 & 0.015 & 0.0381 \\
$\mathrm{Mn}$ & $\mathrm{mg} / \mathrm{L}$ & 20 & 0.4 & 0.1 & 0.0012 & 1.047 & 0.2434 & 0.3269 \\
$\mathrm{Zn}$ & $\mathrm{mg} / \mathrm{L}$ & 20 & - & 1 & 0.0008 & 0.0962 & 0.0109 & 0.0211 \\
$\mathrm{As}$ & $\mu \mathrm{g} / \mathrm{L}$ & 20 & 10 & 10 & 0.456 & 2.57 & 1.066 & 0.566 \\
$\mathrm{Cr}$ & $\mathrm{mg} / \mathrm{L}$ & 20 & 0.05 & 0.05 & 0.002 & 0.0173 & 0.0046 & 0.004 \\
\hline
\end{tabular}



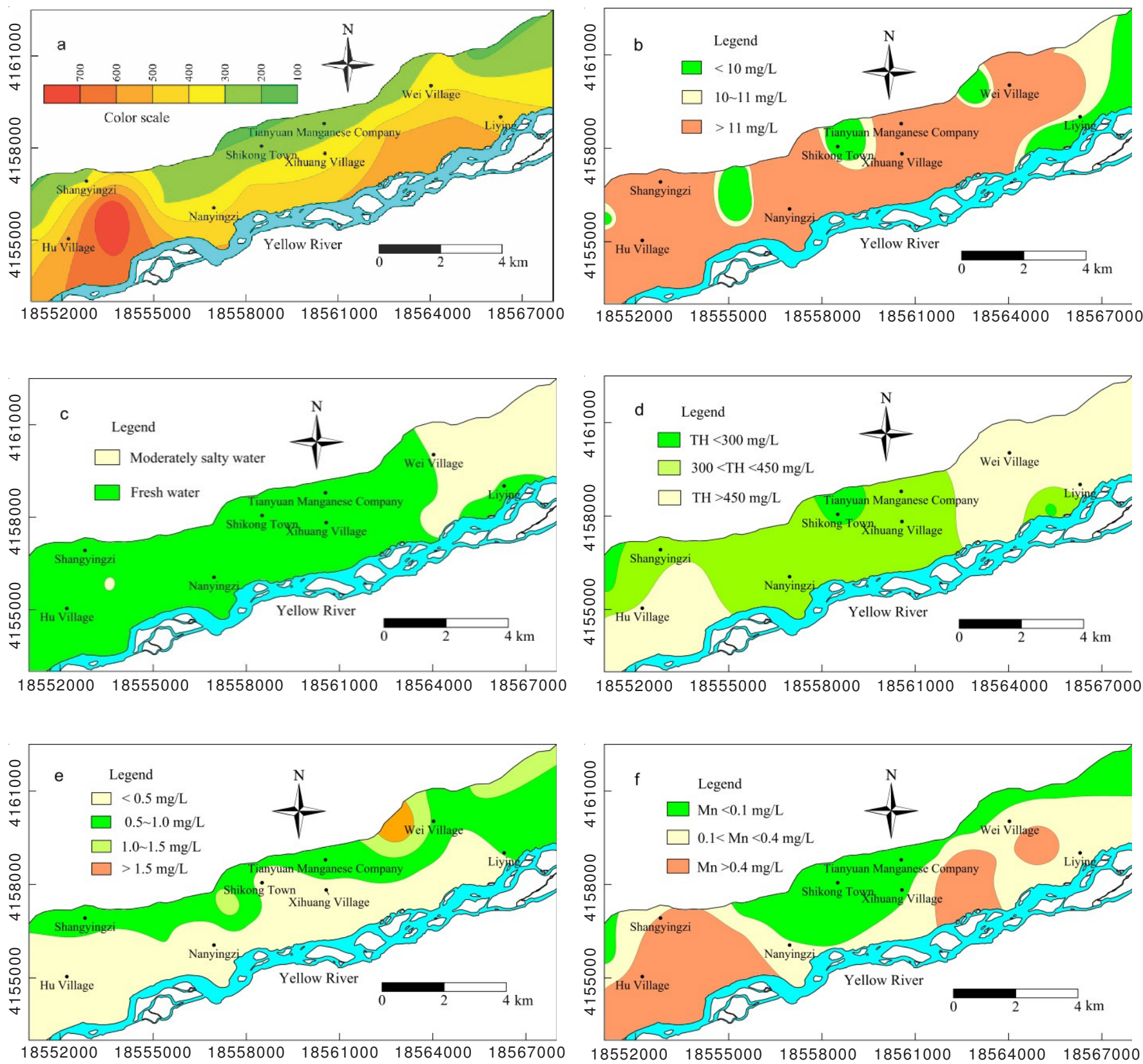

Fig. 2. Spatial distributions of (a) $\mathrm{HCO}_{3}^{-}$, (b) $\mathrm{NO}_{3}-\mathrm{N}$, (c) TDS, (d) total hardness, (e) $\mathrm{F}^{-}$and (f) $\mathrm{Mn}$

The $\mathrm{NO}_{3}^{-}$pollution caused by chemical and organic fertilizer is most common in agricultural regions. The permissible limit of $\mathrm{NO}_{3}-\mathrm{N}$ in drinking water is $10 \mathrm{mg} / \mathrm{L}$ as per the national standard of China. According to the data, 14 samples are not suitable for drinking as per the $\mathrm{NO}_{3}-\mathrm{N}$ level. The highest is $25.74 \mathrm{mg} / \mathrm{L}$ which is more than two times of the standard limit. The high level of $\mathrm{NO}_{3}-\mathrm{N}$ indicates serious anthropogenic pollution in the area. Since this area is a traditional agricultural region and nitrogenous fertilizer is heavily used, which is the major cause of the high level of $\mathrm{NO}_{3}-\mathrm{N}$. Fig. $3 \mathrm{~b}$ has shown that the concentration of $\mathrm{NO}_{3}-\mathrm{N}$ is beyond the permissible limit of both the WHO and the national standards in most part of the area, which suggests that $\mathrm{NO}_{3}-\mathrm{N}$ pollution is serious in the area.

The concentration of TDS is in the range of 414 to 1576 $\mathrm{mg} / \mathrm{L}$ with $25 \%$ beyond the permissible limit of the national

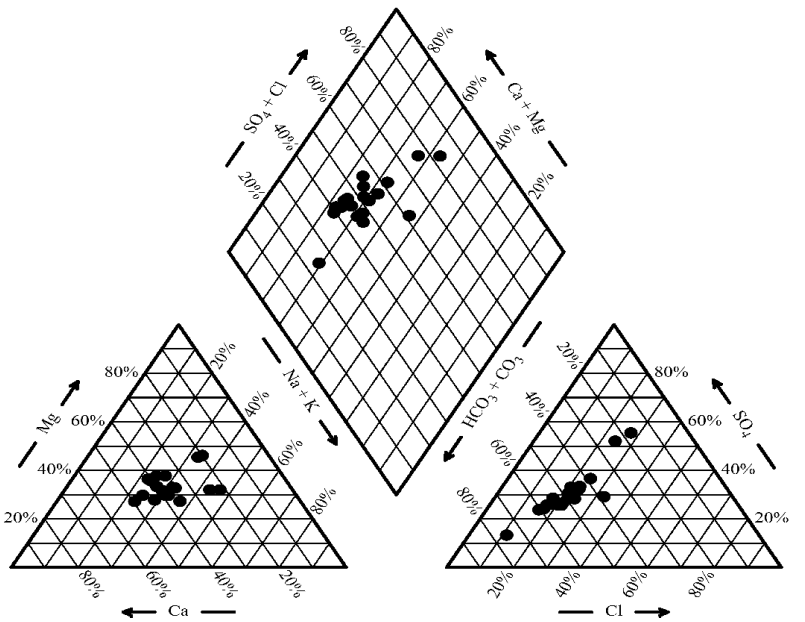

Fig. 3. Piper diagrams of groundwater samples 
standard of China $(1000 \mathrm{mg} / \mathrm{L})$. However, the mean value of TDS is $807.2 \mathrm{mg} / \mathrm{L}$ which represents fresh water. This suggests that when groundwater from different locations are mixed, TDS level of the mixed water will lower and become suitable for drinking. Fig. 3c shows the quality zonation of groundwater as per TDS. It showed that the fresh water (TDS $<1000$ $\mathrm{mg} / \mathrm{L})$ is mainly distributed in the middle and west parts of the area, while moderately salty water $(1000<$ TDS $<3000$ $\mathrm{mg} / \mathrm{L}$ ) can be seen in the east part. Moderately salty water can give human a feeling of salty, which is sometimes unacceptable. Total hardness represents the sum of $\mathrm{Ca}^{2+}$ and $\mathrm{Mg}^{2+}$ in water. As per the data, the total hardness is in the range of 261 to $746 \mathrm{mg} / \mathrm{L}$ and 9 samples have total hardness level higher than the permissible limit of national standard. Moderately hard water $(150<$ total hardness $<300 \mathrm{mg} / \mathrm{L})$ is mainly distributed in the middle and west locally, while hard water $(300<$ total hardness $<450 \mathrm{mg} / \mathrm{L}$ ) and extremely hard water (total hardness $>450 \mathrm{mg} / \mathrm{L}$ ) are widely distributed (Fig. 3d). Extremely hard water is not suitable for domestic use and it mainly distributed in the east and southwest of the area.

Fluoride is a necessary element for human bodies ${ }^{11}$. Too much intake of fluoride may cause serious health problems such as dental fluorosis and crippling fluorosis. The permissible limits of fluoride in the WHO and national standards are 1.5 and $1.0 \mathrm{mg} / \mathrm{L}$, respectively. The maximum value of $\mathrm{F}^{-}$is $2.08 \mathrm{mg} / \mathrm{L}$ in the study which is high. Fig. 3e shows that the samples with higher fluoride content are mainly collected from the north area which is adjacent to the bedrock area where fluoride containing minerals are prevalent. Therefore, the high values of fluoride are mainly caused by natural process as follows:

$$
\mathrm{CaF}_{2} \longrightarrow \mathrm{Ca}^{2+} 2 \mathrm{~F}^{-}
$$

All the heavy metals are in trace contents, but the Mn concentration of some samples are higher than the drinking water standards of the WHO and China. The maximum value of $\mathrm{Mn}$ is $1.047 \mathrm{mg} / \mathrm{L}$ which is more than ten times higher than the permissible limit of China. Mn shows an increasing trend from north to south and more than two-third of the area is covered by groundwater with Mn value higher than $0.1 \mathrm{mg} / \mathrm{L}$. $\mathrm{Mn}$ is a naturally occurring element and it comprises $0.1 \%$ of the crust and occurs in various primary rocks, very often together with iron ${ }^{13}$. However, human activities such as steel production can also deposit manganese into waters. In the present study, 9 samples are having Mn concentration higher than the national standard of China. It is inferred that the high level of Mn in groundwater is caused by both the rock weathering and the production of Tianyuan Manganese Company.

Revealed by the lower left triangle of the Piper diagram (Fig. 3), all samples are plotted in the middle region, indicating mixed type water with respect to cations. With regard to anions, some samples are mixed type water, while some are $\mathrm{HCO}_{3}{ }^{-}$ type and some are $\mathrm{SO}_{4}{ }^{2-}$ type water. Of all samples, the contents of alkaline-earth metals are higher than the alkali metal, because all samples are plotted in the upper left region of the diamond-shaped area. The main hydrochemical types for groundwater in the area are $\mathrm{HCO}_{3}-\mathrm{Ca} \cdot \mathrm{Mg} \cdot \mathrm{Na}, \mathrm{SO}_{4}-\mathrm{Ca} \cdot \mathrm{Mg} \cdot \mathrm{Na}$ and $\mathrm{HCO}_{3} \cdot \mathrm{SO}_{4}-\mathrm{Ca} \cdot \mathrm{Mg} \cdot \mathrm{Na}$.

Water quality assessment: Groundwater quality was assessed using the method introduced above and the calculated water quality indexes were listed in Table-3. The water quality indexes vary in the range of 27.94-128.94. According to the classification standard of groundwater quality (Table-1), five samples are of good quality, accounting $25 \%$ of the total samples. Thirteen samples are of medium quality which may require some treatment for drinking. The good quality water is generally fit for drinking, but it may require some special care of some parameters that have slightly beyond the permissible limits of the standard. Good water is mainly distributed in the middle and the west of the study area where the Tianyuan Manganese Company is located. The water quality indexes are mainly influenced by $\mathrm{NO}_{3}-\mathrm{N}$, total hardness and $\mathrm{Mn}$, since many samples of medium quality have higher values of these parameters.

TABLE-3

CALCULATED ENTROPY WEIGHTS AND WATER QUALITY INDEXES

\begin{tabular}{ccccccccccccccc}
\hline Sample & $\mathrm{SO}_{4}{ }^{2-}$ & $\mathrm{Cl}^{-}$ & $\mathrm{TDS}$ & $\mathrm{pH}$ & $\mathrm{NO}_{3}-\mathrm{N}$ & $\mathrm{F}^{-}$ & $\mathrm{TH}$ & $\mathrm{Cu}$ & $\mathrm{Mn}$ & $\mathrm{Zn}$ & $\mathrm{As}$ & $\mathrm{Cr}$ & $\mathrm{EWQI}$ & $\mathrm{Rank}$ \\
\hline $\mathrm{W} 11$ & 2.74 & 1.62 & 3.28 & 4.46 & 6.00 & 3.04 & 4.62 & 0.05 & 0.44 & 0.04 & 0.97 & 0.69 & 27.94 & II \\
$\mathrm{W} 19$ & 3.57 & 2.23 & 3.96 & 4.97 & 7.30 & 3.47 & 4.88 & 0.05 & 0.11 & 0.01 & 0.66 & 0.47 & 31.69 & II \\
$\mathrm{W} 15$ & 3.25 & 1.92 & 3.83 & 4.66 & 6.98 & 5.03 & 5.31 & 0.04 & 0.14 & 0.01 & 0.49 & 0.54 & 32.21 & II \\
$\mathrm{W} 9$ & 3.44 & 1.77 & 4.55 & 3.95 & 10.10 & 3.91 & 6.30 & 0.04 & 0.27 & 0.04 & 1.09 & 0.83 & 36.29 & II \\
$\mathrm{W} 13$ & 4.09 & 1.99 & 5.62 & 3.04 & 11.61 & 3.65 & 7.24 & 0.17 & 0.10 & 0.10 & 0.42 & 0.40 & 38.42 & II \\
$\mathrm{W} 10$ & 6.27 & 3.09 & 6.03 & 4.46 & 14.78 & 5.90 & 6.26 & 0.12 & 0.98 & 0.19 & 1.36 & 1.98 & 51.45 & III \\
$\mathrm{W} 14$ & 5.49 & 2.91 & 6.15 & 3.85 & 20.55 & 2.00 & 7.66 & 0.05 & 1.84 & 0.05 & 0.67 & 0.41 & 51.65 & III \\
W8 & 2.92 & 1.69 & 3.27 & 6.49 & 5.19 & 18.06 & 10.58 & 1.57 & 0.29 & 0.85 & 2.23 & 1.10 & 54.25 & III \\
W1 & 6.85 & 3.08 & 7.72 & 3.25 & 5.26 & 2.69 & 4.72 & 0.04 & 25.77 & 0.01 & 0.84 & 0.43 & 60.68 & III \\
W12 & 4.97 & 4.05 & 6.49 & 5.68 & 18.39 & 11.29 & 7.73 & 0.04 & 0.28 & 0.04 & 1.07 & 1.28 & 61.31 & III \\
W7 & 6.59 & 3.50 & 8.12 & 3.35 & 10.01 & 2.17 & 10.58 & 0.04 & 18.58 & 0.08 & 0.67 & 0.40 & 64.09 & III \\
W3 & 13.06 & 4.72 & 8.50 & 6.08 & 8.74 & 10.16 & 8.65 & 0.05 & 0.83 & 0.02 & 1.78 & 1.77 & 64.36 & III \\
W16 & 3.61 & 2.22 & 4.09 & 4.87 & 4.58 & 4.51 & 5.33 & 0.05 & 39.12 & 0.14 & 0.62 & 0.45 & 69.58 & III \\
W2 & 7.89 & 3.60 & 7.82 & 2.84 & 8.24 & 4.60 & 9.56 & 0.06 & 23.36 & 0.20 & 0.85 & 3.12 & 72.13 & III \\
W4 & 17.80 & 6.10 & 12.46 & 3.75 & 13.32 & 4.34 & 13.20 & 0.05 & 0.38 & 0.02 & 1.08 & 0.76 & 73.28 & III \\
W18 & 4.35 & 2.21 & 4.97 & 3.85 & 15.36 & 5.56 & 6.19 & 0.05 & 30.31 & 0.04 & 0.40 & 0.36 & 73.65 & III \\
W20 & 5.23 & 2.55 & 6.63 & 4.06 & 12.77 & 2.52 & 8.81 & 0.05 & 38.52 & 0.02 & 0.46 & 0.36 & 81.97 & III \\
W5 & 8.83 & 4.47 & 8.92 & 2.74 & 13.52 & 2.95 & 10.25 & 0.04 & 46.70 & 0.01 & 0.49 & 0.43 & 99.35 & III \\
W6 & 5.98 & 3.34 & 7.05 & 4.26 & 13.34 & 5.64 & 8.56 & 0.04 & 75.42 & 0.01 & 1.56 & 0.41 & 125.62 & IV \\
W17 & 3.64 & 2.27 & 8.22 & 3.14 & 14.26 & 3.13 & 9.87 & 0.06 & 83.16 & 0.06 & 0.75 & 0.38 & 128.94 & IV \\
\hline
\end{tabular}


The Tianyuan Manganese Company has claimed that the smelting plant has introduced an advanced production process so that nearly all waste water that produced during the production has been treated and recycled. However, based on our field investigation, a drain ditch that drains wastewater is running just in the south of the plant. Thus it can be guessed that the plant has discharged waste water slinkingly. This is harmful to the environment and human health, because waste water contains heavy metals that are extremely harmful to human health and plant growth. Groundwater is generally of good quality currently suggested by the water quality indexes, but it can be concluded that groundwater quality will degrade in future.

\section{Conclusion}

In the present study, groundwater in the Zhongning Shikong industrial area was assessed using the entropy weighted water quality index. The study shows most physiochemical parameters except $\mathrm{HCO}_{3}^{-}, \mathrm{NO}_{3}-\mathrm{N}$, TDS, total hardness, $\mathrm{F}^{-}$and $\mathrm{Mn}$ are all within the permissible limits of WHO standard or national standard of China. The over-limit contents of $\mathrm{HCO}_{3}^{-}$, TDS, total hardness and $\mathrm{F}^{-}$are caused mainly by natural rock weathering processes, while that of $\mathrm{NO}_{3}-\mathrm{N}$ is caused by human agricultural activities and the high content of $\mathrm{Mn}$ in groundwater is induced by both natural and human processes. The water quality indexes range from 27.94 to 128.94 . Thirteen samples are of medium quality, 5 are of good quality and the other 2 are of poor quality. The high water quality indexes are caused by the excess $\mathrm{NO}_{3}-\mathrm{N}$, total hardness and Mn which are mostly human induced.

\section{ACKNOWLEDGEMENTS}

The research was supported by the Doctor Postgraduate Technical Project of Chang'an University (2013G5290002 and CHD2011ZY022), the Special Fund for Basic Scientific Research of Central Colleges (CHD2011ZY020 and CHD2012TD003) and the National Natural Science Foundation of China (41172212).

\section{REFERENCES}

1. Z.S. Han, Environ. Geol., 44, 106 (2003).

2. W.L. Zhang, Z.X. Tian, N. Zhang and X.Q. Li, Agric. Ecosys. Environ., 59, 223 (1996).

3. O. Emteryd, D.Q. Lu and N. Nykvist, AMBIO: A J. Human Environ., 27, 441 (1998).

4. X.T. Ju, X.J. Liu, F.S. Zhang and M. Roelcke, AMBIO: A J. Human Environ., 33, 300 (2004).

5. J.Y. Chen, C.Y. Tang, Y. Sakura, J.J. Yu and Y. Fukushima, Hydrogeol. J., 13, 481 (2005).

6. J.Y. Chen, M. Taniguchi, G.Q. Liu, K. Miyaoka, S. Onodera, T. Tokunaga and Y. Fukushima, Hydrogeol. J., 15, 1605 (2007).

7. P.Y. Li, H. Qian and J.H. Wu, E-J. Chem., 8, 851 (2011).

8. P.Y. Li, J.H. Wu and H. Qian, Environ. Monit. Assessm., 184, 4841 (2012).

9. A.A. Bordalo, R. Teixeira and W.J. Wiebe, Environ. Manage., 38, 910 (2006).

10. G.B. Chaturvedi, B.B. Mishra and D.D. Tewari, Nature Environ. Pollut. Technol., 7, 331 (2008).

11. P.Y. Li, H. Qian and J. H.Wu, E-J. Chem., 7, S209 (2010).

12. J.H. Wu, P.Y. Li and H. Qian, E-J. Chem., 8, 787 (2011).

13. K. Ljung, M. Vahter and M. Berglund, Manganese in Drinking Water, IMM-rapport nr 1/2007, Stockholm: Karolinska Institutet (2007). 